\title{
Decision Support System to Choose Digital Single Lens Camera with Simple Additive Weighting Method
}

\author{
Tri Pina Putri ${ }^{1}$, Paulina H. Prima Rosa ${ }^{2}$ \\ ${ }^{1,2}$ Department of Informatics, Faculty of Science and Technolgy, Sanata Dharma University \\ Email: ${ }^{1}$ tripina666@ gmail.com, ${ }^{2}$ rosa@usd.ac.id
}

\begin{abstract}
One of the technologies that evolve today is Digital Single Lens Reflex (DSLR) camera. The number of products makes users have difficulties to choose the appropriate camera based on their criteria. Users may utilize several ways to help them choosing the intended camera such as using magazine, internet, and other media. This paper discusses about a web based decision support system to choose cameras by using SAW (Simple Additive Weighting) method in order to make the decision process more effective and efficient. This system is expected to give recommendations about the camera which is appropriate with the user's need and criteria based on the cost, the resolution, the feature, the ISO, and the censor. The system was implemented by using PHP and MySQL. Based on the result of questionnaire distributed to 20 respondents, $60 \%$ respondents agree that this decision support system can help users to choose the appropriate camera DSLR in accordance with the user's need, $60 \%$ of respondents agree that this decision support system is more effective to choose DSLR camera and $75 \%$ of respondents agree that this system is more efficient. In addition, $60.55 \%$ of respondents agree that this system has met 5 Es Usability Framework.
\end{abstract}

Keywords: Simple additive weighting (SAW), decision support system (DSS), DSLR camera.

\section{INTRODUCTION}

In this digital era, technologies have been part of any aspects of human life. Technologies help people to solve many problems. One of the technologies that evolve today is Digital Single Lens Reflex (DSLR) camera. A DSLR camera is a digital camera that uses processor, chip, memory, and other advanced technologies to capture image by using one single lens embedded in camera body [1]. Many number of high qualified camera products equipped with advanced technologies can be found in the market to fulfill costumers needs [2].

Usually, costumers utilize several ways to help them choosing the intended camera such as using magazine, internet, flyers, and word of mouth. After getting enough information, costumers usually compare the information with available budget as well as their particular needs. This way is effective but is not efficient due to the time and cost needed to gather information. Furthermore, various number of products makes costumers have difficulties to choose the appropriate camera based on their own criteria.

Based on the above mentioned problem, the authors developed a decision support system to help costumers choosing suitable camera based on their own criteria. The system was developed using Simple Additive Weighting method. 


\section{METHOD}

\subsection{Fundamental Theory}

\subsubsection{Decision Support System}

A decission support system can be defined as a system that has ability to provide solution for semi-stuctured problem [3]. A decision support system as a system may support the performance of a manager or a group of managers in solving semistructured problem by providing information or recommendation towards a particular solution.

A decision support system can solve several type of problems as follows [3]:

1. Structured decision

Structured decision is a routine decision which is performed repeatedly. The procedure to make decision is clear. This type of decision usually can be found in low level management.

2. Semistructured decision

Semistuctured decision is a decision that has two characteristics. One part of the system will be handled by computers, while the other part should be handled by the decision maker. The procedure to make decision exists in general. However, several steps of the procedure need decision maker policy. Usually this type of decision is taken by middle level managers.

3. Unstructured decision

Unstructured decision is a complex decision which is not repeated or not always happened. This type of decision require experiences and various external resources. It is usually found in the high level management.

The application of a decision support system consists of several subsystems [4], namely :

1. Data management subsystem

Data management subsystem contains a database which is relevant to the problem. The database will be managed with a Data Base Management System.

2. Model management subsystem

Model management subsystem contains quantitative model such as financial, statistics, scientific management, or other quantitative models to give analytical capability to the decision support system.

3. Dialog management subsystem

Dialog management subsystem contains facilities for users to communicate with the system via user interfaces.

4. Knowledge management subsystem

Knowledge management subsystem contains support to the three other subsystems. This subsystem is optional. Usually the subsystem can be found in the decision of a complex problem. A decision support system which contain knowledge management subsystem known as knowledge-based decision support system. 


\subsubsection{Simple Additive Weighting}

Simple Additive Weighting (SAW) method is the simplest and still the widest used Multi Atribute Decision Making (MADM) method [5]. In this method, each attribute is given a weight and the sum of all weights must be 1.The basic concept of SAW is finding weighted sum of performance rating of each alternative over all attributes. SAW method will construct a decision matrix, normalize the matrix, and then multiply the matrix with the weight of each attribute.

The step wise procedure of SAW is given below [6][7]:

1. Let $\mathrm{C}=\left(\mathrm{c}_{1}, \mathrm{c}_{2}, \mathrm{c}_{3}, \ldots, \mathrm{c}_{\mathrm{n}}\right)$ be a set of criteria and $\mathrm{A}=\left(\mathrm{a}_{1}, \mathrm{a}_{2}, \mathrm{a}_{3}, \ldots, \mathrm{a}_{\mathrm{m}}\right)$ be a set of alternatives.

2. Construct a weighted vector $\mathrm{W}_{\mathrm{j}}$ for every alternatives in which $\sum_{j=1}^{m} w_{j}=1$

3. Construct a decision matrix $D$, where $d_{i j}$ is the rating of alternative $A_{i}$ with respect to criterion $\mathrm{C}_{\mathrm{j}}$.

4. Construct the normalized decision matrix with the following rule:

- For beneficial attribute (criteria of benefit):

$$
\mathrm{r}_{\mathrm{ij}}=\frac{d_{i j}}{\max d_{i j}}
$$

- For non beneficial attribute (criteria of cost):

$$
\mathrm{r}_{\mathrm{ij}}=\frac{\min x_{i j}}{x_{i j}}
$$

5. Construct weighted normalized decision matrix :

$$
V_{i j}=w_{i} r_{i j}
$$

6. Calculate the score of each alternative:

$$
S_{i}=\sum_{j=1}^{m} V_{i j}
$$

7. Rank the alternatives in descending order. The highest score is the best alternative solution.

\subsubsection{Es Usability Framework}

5 Es Usability Framework is a framework that can be used to help in evaluating usability of a software system. It consists of 5 aspects namely:

1. Effective: how a software can be utilized to achieve the objectives of users. The software system is effective when it is able to help users achieving their objectives. Therefore, the system should be relevant which mean able to fullfill users needs, able to answer users questions, and ablt to help users accomplished their tasks.

2. Efficient: how fast the task will be accomplished by using the system. Navigation elements such as menu, link, and other buttons give impacts to the efficiency. 
3. Engaging: how good the user interface is for its users to help them interact with the system. The design on visual elements play important roles in this aspects.

4. Error tolerant: how good the system will be able to prevent error an how helpfull the application able to help users recover from errors when it happened.

5. Easy to learn: how good the system support users to learn using the system and exploring the features of the system.

\subsection{Methods}

The system was developed with the following steps:

1. Planning phase: determine the goal and objective of the decision support system.

2. Data gathering through the following activities:

a. Interview and distribute questionnaire to a student photography community to determine the criteria that will be used in the system.

b. Collect camera specification through the site www. Canon.co.id and Cameradecision.com.

c. Literature study to explore the model of decision making.

3. Develop the system by applying Framework of Application System Thinking (FAST) methodology [8] to design and implement 3 components of decision support system namely data management subsystem, model management subsystem, and dialog management subsystem. Knowledge management subsystem was not applied in this system.

4. Perform system testing by applying black box testing and users testing. Black box testing was performed by trying all use cases and scenarios to find out whether all features functioned nornally. In the users testing, 20 users were asked to use the system an evaluate the system by using a questionnaire which is composed using 5 Es Usability Framework.

5. Analyze the validity, effecivity, and efficiency of the system based on the result of the testing.

6. Conlude the analysis.

\section{RESULTS AND DISCUSSIONS}

\subsection{System Design}

The system was designed for two categories of users namely administrator and users. There are two clusters of functions provided for administrator as follows:

1. Managing cameras: add, edit, delete, and browse cameras and the corresponding specifications.

2. Managing criterias: add, edit, delete, and browse criteria to be used by users. Meanwhile, users have the following functions:

1. Browsing all cameras stored in the databases

2. Choosing particular cameras to be compared by determining certain interval of prices

3. Asking for recommendations from the system. 
The process of determining recommendations by the system is described in figure 1 .

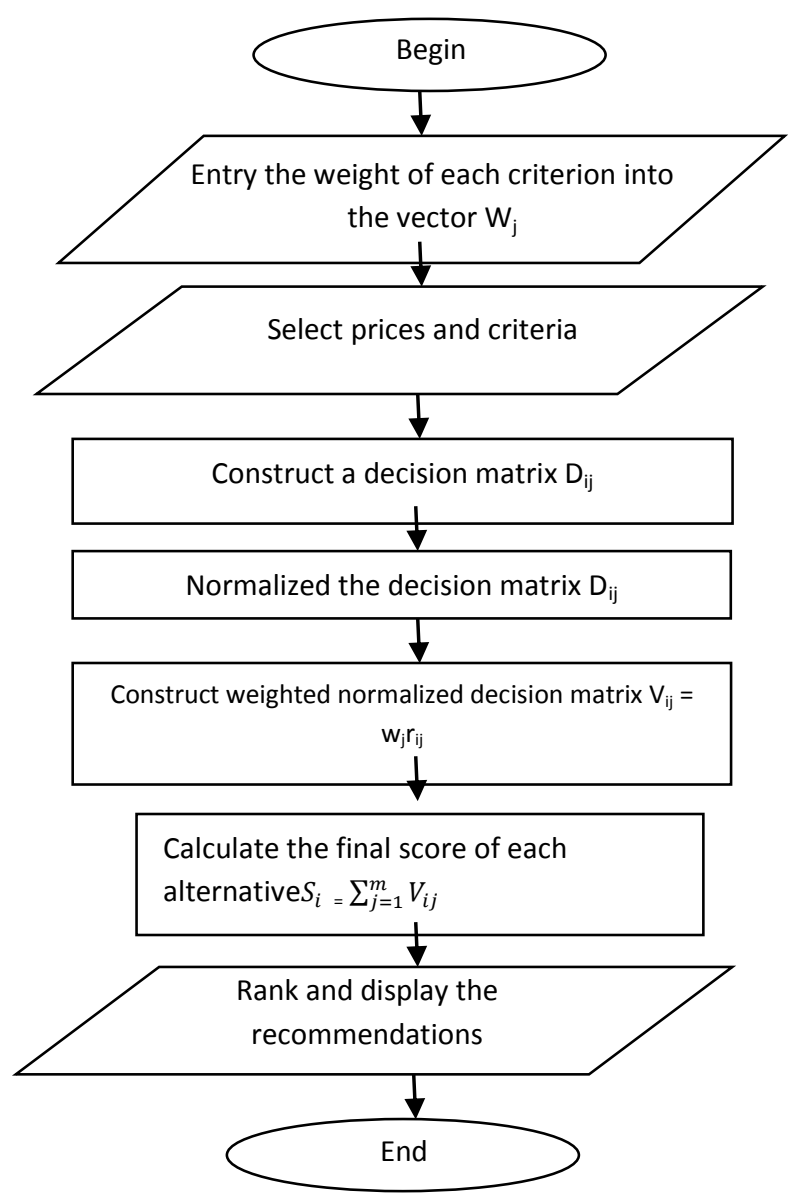

Figure 1. Flowchart of the system

\subsection{System Implementation}

The system was implemented as a web based decision support system by using PHP and MySQL. Figure 2 describes the home page of the system. Figure 3 is the page to entry the weight of each criteria, while figure 4 is the page to select prices of cameras as well as criteria. Figure 5 is the page to display the recommendation of the system. 


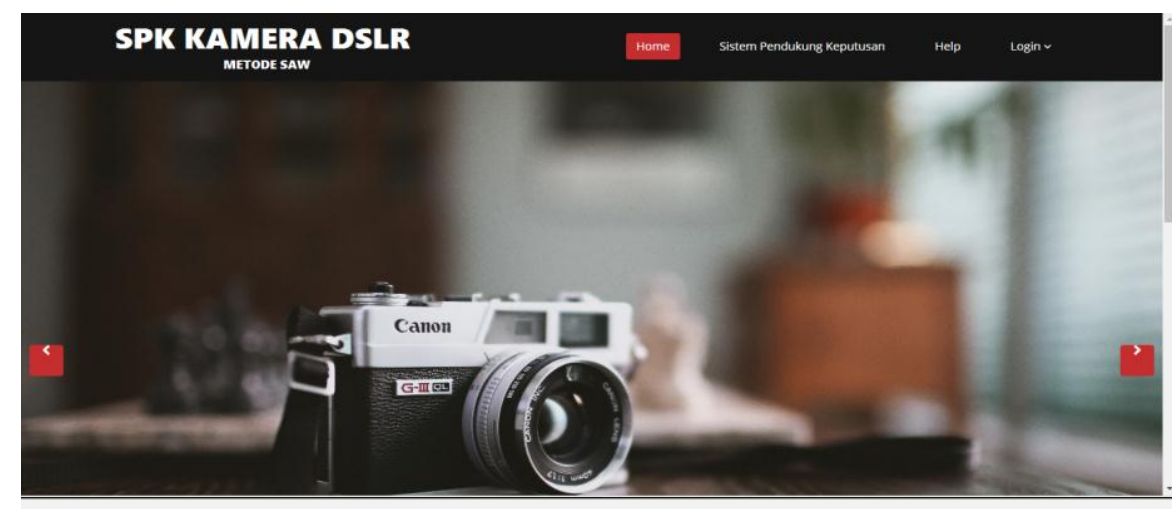

\section{Sistem Rekomendasi Pemilihan Kamera DSLR}

\begin{tabular}{|c|c|c|}
\hline Lihat Detail Kamera & Proses SPPK & Hasil Rekomendasi \\
\hline $\begin{array}{l}\text { Proses Melihat Spesiffikasi } \\
\text { Kamera }\end{array}$ & $\begin{array}{l}\text { Proses perhitungan } \\
\text { menggunakan metode SAW }\end{array}$ & $\begin{array}{l}\text { Menyimpan File hasil SPPK ke } \\
\text { dalam sebuah folder/PDF }\end{array}$ \\
\hline Lihat Rekomendasi & Banding Kamera & Kamera Pilihan \\
\hline $\begin{array}{l}\text { Melihat Hasil Dari Proses } \\
\text { Rekomendasi Kamera } \\
\text { Terbaik }\end{array}$ & $\begin{array}{l}\text { Membandingkan Beberapa } \\
\text { Pilihan Kamera Yang Akan } \\
\text { Dibandingkan }\end{array}$ & $\begin{array}{l}\text { Menampilkan Semua Pilihan } \\
\text { Kamera }\end{array}$ \\
\hline
\end{tabular}

Figure 2. Home Page of the System

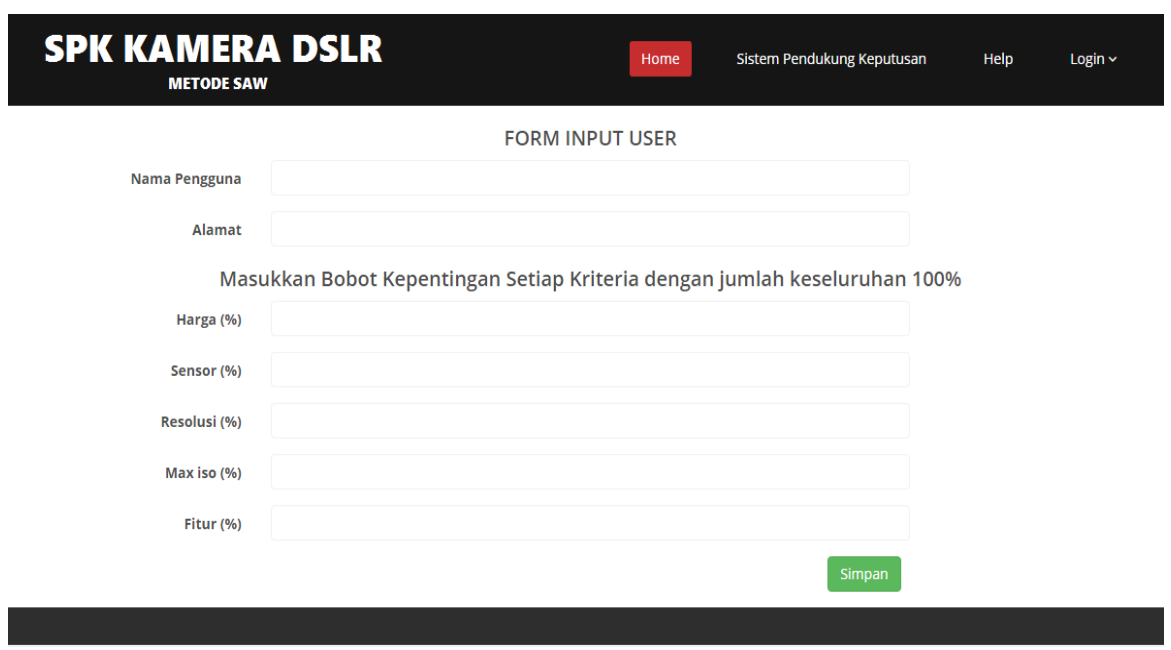

Figure 3. Page to Entry the Weight 
Sistem Pendukung Keputusan Pemilihan Kamera DSLR

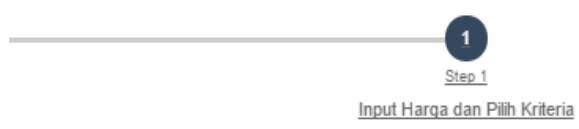

Step 1

1. Input budget kamera yang ingin dicari

2. Pilih kriteria yang akan dbandingkan minimal 3 kriteria.

3. Input bobot kepentingan setiap kriteria dengan total $100 \%$

4. Untuk simpan hasil pilihan tekan button simpan dibagian pojok kiri bawah.

III Filter Harga Dan Kriterla

Harga Rendah < Rp.5.218.997, Harga Tinggi > Rp.9.851.458, Harga

Sedang antara Rp.5.218.997 - Rp.9.851.458

Cari Harga Kamera Sekitar? (Rp) :

4500000

1. Bobot Harga \% :

, 30

2. Bobot Sensor \%:

, 30

3. Bobot Resolusi \%

- 40

4. Bobot Fitur $\%$

5. Bobot Max ISO \%:

Simpan

Figure 4. Page to Select Price and Criteria 


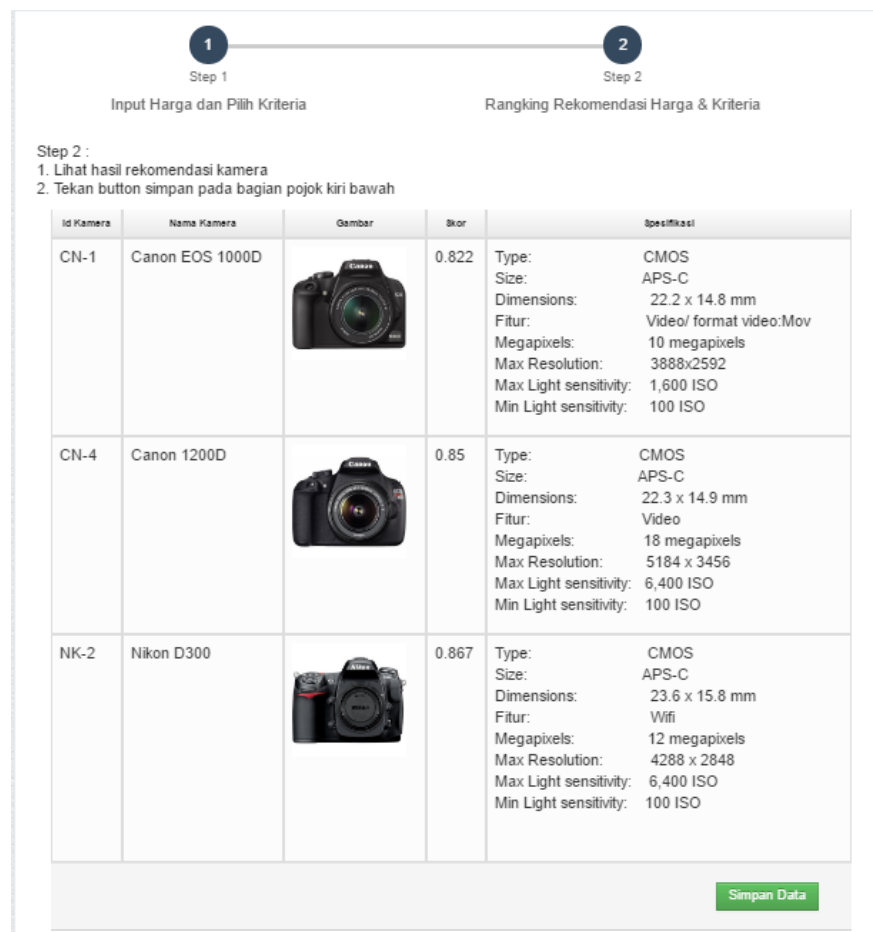

Figure 5. Recommendation of the System

\subsection{System Testing}

\subsubsection{Black Box Testing}

A black box testing was performed by try each use case of the system to check wether it performs as expected or not. Based on the black box testing, it can be concluded that the system is able to produce output as expected by users and able to handle errors when the functions do not perform normally.

\subsubsection{Users Testing}

The system was also tested towards 20 respondents who were asked to try the system and then to fill up a questionnaire. The result of the questionnaire is described in table 1 as follows. 
Table 1. The Result of Users Questionnaire

Question

VA A D

1. The system can support decision making to choose DSLR camera.

$40 \% \quad 60 \%$

2. Using this system, the process of choosing DSLR camera is more effective.

$40 \% \quad 60 \%$

3. Using this system, the process of choosing DSLR camera is more efficient.

4. The features of the system can be used effectively by users.

$30 \% \quad 55 \% \quad 15 \%$

5. The features of the system can be used efficiently by users.

$25 \% \quad 60 \% \quad 15 \%$

6. The features of the system can be used understood by users.

$20 \% \quad 55 \% \quad 15 \% \quad 10 \%$

7. The features of the system help users to choose criteria based on users' intentions.

$10 \% \quad 75 \% \quad 15 \%$

8. The features of the system ease users to manage relative weight of importance of each criterion.

9. The features of the system ease users to choose DSLR camera based on the price and users criteria.

$30 \% \quad 65 \% \quad 5 \%$

10. The features of the system ease users to compare particular DSLR cameras as users want.

$30 \% \quad 65 \% \quad 5 \%$

11. The feature to print the result of recommendation ease users to look carefully the recommendations of the system.

$35 \% \quad 55 \% \quad 10 \%$

12. The steps to display recommedation are understandable.

$10 \% \quad 50 \% \quad 40 \%$

13. The user interface of the system is interesting and ease users to use the system.

14. The guideline and help features provided in the system can ease users to use the system.

$\begin{array}{lll}40 \% & 55 \% & 5 \% \\ 20 \% & 70 \% & 10 \% \\ & & \\ 20 \% & 70 \% & 10 \% \\ & & \\ 35 \% & 55 \% & 10 \%\end{array}$

*) VA = Very Agree, A = Agree, D = Doubt, NA = Not Agree, VNA = Very Not Agree 


\section{CONCLUSION}

Based on the system and user testing, it can be concluded that the web-based decision support system to choose DSLR camera by using Simple Additive Weghting method has been successfully developed. The system has met users' requirements and criterion. $60 \%$ of respondents agree that this decision support system is more effective to help users choose DSLR camera and 75\% of respondents agree that this system is more efficient. In addition, $60.55 \%$ of respondents agree that this system has met 5 Es Usability Framework. Future work to improve usability of the system is recommended.

\section{REFERENCES}

[1] Syndicate, R. 2011. Fotografi Digital dengan DSLR. JALPublishing, Yogyakarta.

[2] JawaPos. 2016. Canon-pimpin-pasar-dslr-selama-13-tahun. http://JawaPos.com, diakses 15 juni 2016.

[3] Kusrini, 2011. Konsep dan Aplikasi Sistem Pendukung Keputusan. Andi, Yogyakarta.

[4] Turban, E. 1995. Decision Support Systems and Expert System. Prentice-Hall, New York.

[5] Gayatri, V. \& Chetan, M. 2013. Comparative Study of Different Multicriteria Decision-making Methods. International Journal of Advanced Computer Theory and Engineering (IJACTE). Volume-2 Issue-4: 9-12.

[6] Adriyendi. 2015. Multi-Attribute Decision Making Using Simple Additive Weighting and Weighted Product in Food Choice. I.J. Information Engineering and Electronic Business, Vol. 6: 8-14.

[7] Kusumadewi, S., 2006. Fuzzy-Attribute Decision Making (Fuzzy MADM). Graha Ilmu, Yogyakarta.

[8] Whitten, J.L.. 2004. System Analysis and Design Methods 6 th edition. McGraw Hill, New York. 